\title{
Differences in physiological energetics between intertidal and raft cultivated mussels Mytilus galloprovincialis
}

\author{
U. Labarta*, M. J. Fernández-Reiríz, J. M. F. Babarro \\ C.S.I.C. Instituto de Investigaciones Marinas, c/Eduardo Cabello, 6, E-36208 Vigo, Spain
}

\begin{abstract}
Methods of physiological energetics were applied to compare growth rates of mussels Mytilus galloprovincialis Lmk. from 2 habitats: intertidal and raft cultures. Scope for growth was determined after 1 and 15 d under standard laboratory conditions. Both groups of mussels improved their growth potential during maintenance in the laboratory due to a combination of increased ingestion rate and decreased metabolic rate. Cultivated mussels presented higher weight-specific clearance rates, higher absorption efficiency and higher rates of ammonia excretion, which resulted in increased scope for growth with respect to intertidal mussels. This finding is related to the differential characteristics of these 2 habitats in terms of cycles of food availability and air exposure. Differences between the groups of mussels persisted after $15 \mathrm{~d}$ of experimental treatment and were mainly accounted for by absorption efficiency.
\end{abstract}

KEY WORDS: Mussel - Physiological energetics Clearance rate - Metabolic rate Absorption efficiency Ammonia excretion rate - Scope for growth (SFG) - Net growth efficiency $\left(K_{2}\right)$

\section{INTRODUCTION}

Mussels tolerate a wide range of environmental conditions by adjusting physiological responses in order to achieve maximum rates of growth. Thus, the distinctive physiological behaviour observed in mussels from different origins can be viewed in the perspective of adaptation to the particular environmental conditions experienced by any population.

Cultivated mussels exist under nutritional conditions quite different from those faced by intertidal specimens. Firstly, fluctuations in both the concentration and quality of suspended matter are frequent in the intertidal area while seston composition is comparatively stable in the area of cultivation. Secondly, intertidal mussels undergo periods of air exposure, when feeding becomes suppressed. There is empirical evidence showing that any of these factors can exert a

\footnotetext{
·E-mail: labarta@iim.csic.es
}

profound influence on physiology and growth (Bayne et al. 1984, 1987, 1989, Peterson \& Black 1988).

Accordingly, the aims of this work were to test whether previous conditioning affects physiological responses of mussels by applying physiological energetics methods to compute growth rate in specimens from 2 origins: intertidal and raft cultivated. Also, measurements were undertaken after 1 and $15 \mathrm{~d}$ in order to ascertain the persistence of physiological traits under standard experimental conditions.

\section{MATERIALS AND METHODS}

Harvesting and maintenance of mussels. Mytilus galloprovincialis Lmk of about $60 \mathrm{~mm}$ shell length were collected from 2 habitats (intertidal and raft cultures) within Ría de Arousa (Galicia, NW Spain) during July 1995. After the epifauna was scraped from the shells, specimens were placed, 50 each, in $19 \mathrm{l}$ tanks in the laboratory, where they were maintained in an open circuit of sea water with constant seston 
Table 1. Shell length $(\mathrm{mm})$ and dry weight $(\mathrm{g})$ (mean $\pm \mathrm{SD}$ ) of mussels used in experiments after 1 and $15 \mathrm{~d}$ maintenance in the laboratory

\begin{tabular}{|cccc|}
\hline Day & Origin & Shell length & Dry weight \\
& Intertidal & $57.33 \pm 1.73$ & $1.34 \pm 0.25$ \\
& Raft & $58.25 \pm 2.53$ & $0.72 \pm 0.21$ \\
15 & Intertidal & $57.00 \pm 1.75$ & $1.20 \pm 0.28$ \\
& Raft & $58.71 \pm 2.05$ & $0.67 \pm 0.22$ \\
\hline
\end{tabular}

concentration $\left(1.04 \pm 0.05 \mathrm{mg} \mathrm{l}^{-1}\right)$, temperature (14 to $\left.15^{\circ} \mathrm{C}\right)$ and salinity $(33 \%)$.

First physiological measurements were undertaken after the individuals had been maintained for $12 \mathrm{~h}$ under these conditions within the experimental system.

Mean values of shell size and dry weight for the different groups of mussels used in this experiment are presented in Table 1.

Experimental diet. The experimental diet was designed so as to reproduce the annual average values of total particulate matter (TPM; $\mathrm{mg} \mathrm{l}^{-1}$ ), hence particulate organic matter (POM; $\mathrm{mg} \mathrm{l}^{-1}$ ), and \% organic matter observed in Ría de Arousa.

This diet comprised 2 particulate components: Tahitian Isochrysis aff. galbana (T-ISO) cells, and sediments from underneath the bottom of a raft that had been preserved freeze-dried. These components were mixed in the proportion of $40: 60(w / w)$ for the algae and sediment, respectively.

The diet was dosed to the tanks from a concentrated stock at the appropriate rate so as to obtain the aimed value of $0.56 \mathrm{mg} \mathrm{POM} \mathrm{l}^{-1}$. To avoid sedimentation, the particulate material was kept constantly in suspension by means of strong aeration.

Replicate samples of sea water taken from the feeding tanks (from 1 to 1.51 ) were filtered on previously washed $(3 \times 10 \mathrm{ml}$ distilled water) Whatman $\mathrm{GF} / \mathrm{C}$ filters and ashed $\left(450^{\circ} \mathrm{C}\right.$ for $\left.4 \mathrm{~h}\right)$. Later, the filters were washed with a sea water isotonic ammonium formate solution $(0.5 \mathrm{M})$ to eliminate salts and dried at $110^{\circ} \mathrm{C}$ Weight increment recorded in the filters served to compute TPM. POM was computed from the weight loss on ignition at $450^{\circ} \mathrm{C}$ for $4 \mathrm{~h}$ in a MUFLA furnace. Mean values of these samples $( \pm \mathrm{SD})$ are shown in Table 2 .

The particulate volume was determined by means of a Coulter Multisizer fitted with a $100 \mu \mathrm{m}$ pore opening tube. Particle concentration measured in terms of total volume was monitored during the experiment and maintained at the set value by means of frequent adjustments of the dosing rate. The quality of the diet was expressed in terms of both organic content and organic density ( $\mathrm{mg}$ POM $\mathrm{mm}^{-3}$ ). According to Bayne et al. (1987), this last measurement of quality is more representative of the energy available to suspension feeders when fed heterogeneous diets as in the present experiments

Physiological measurements. Clearance (CR, $\left.I \mathrm{~h}^{-1}\right)$ and ingestion rates ( $I R, m g$ org $\left.h^{-1}\right)$ : The clearance rate (CR) was determined individually in a flowthrough system within $350 \mathrm{ml}$ chambers by recording the concentration of particles $>3 \mu \mathrm{m}$ in water samples taken at the inflow and outflow of the chamber with a Coulter Multisizer. Before the start of experiments, mussels were kept in the chambers for $1 \mathrm{~h}$ with flowing sea water at the experimental particle concentration to allow for valve opening and acclimation to the chamber conditions.

CR was calculated following the Hildreth \& Crisp (1976) equation

$$
\left.C R=f\left[\left(C_{i}-C_{o}\right) / C_{m}\right)\right]
$$

where $f$ is the flow rate $l=9.91 \pm 0.31 \mathrm{l} \mathrm{h}^{-1}$, in the present experiments), $C_{1}$ and $C_{0}$ are food concentrations at the inflow and outflow of the chamber, and $C_{m}$ represents the particle concentration surrounding the mussel.

Pérez-Camacho González (1984) and Widdows \& Johnson (1988) used the entrance concentration as representative of $C_{m}$ for $C R$ calculations. However, in a preliminary run we observed that $C_{m}$ was close to $C_{0}$, so $C_{0}$ was subsequently used as the reference concentration.

The organic ingestion rate $\left(\mathrm{IR}, \mathrm{mg}\right.$ org $\left.\mathrm{h}^{-1}\right)$ was calculated as a product of CR and the food concentration (mg POM I-1)

Efficiencies and rates of absorption: Samples of the food suspension and the faeces produced over $4 \mathrm{~h}$ were collected twice for each individual mussel. Both food and faeces were filtered on Whatman GF/C filters and processed for TPM and POM computation according to previously described methods.

Table 2. Characteristics of the expenmental diet. TPM: total particulate matter; POM: particulate organic matter; Vol: total particulate volume; \% org.: \% organic content (by weight); Q: quality or organic density

\begin{tabular}{|rccccc|}
\hline Day & $\begin{array}{c}\text { TPM } \\
\left(\mathrm{mg} \mathrm{l}^{-1}\right)\end{array}$ & $\begin{array}{c}\text { POM } \\
\left(\mathrm{mg} \mathrm{l}^{-1}\right)\end{array}$ & $\begin{array}{c}\text { Vol. } \\
\left(\mathrm{mm}^{3} \mathrm{l}^{-1}\right)\end{array}$ & $\%$ org. & $\begin{array}{c}\text { Q } \\
\text { POM/Vol. }\end{array}$ \\
\hline 1 & $1.07 \pm 0.10$ & $0.56 \pm 0.15$ & $1.28 \pm 0.25$ & $52.55 \pm 3.65$ & $0.437 \pm 0.085$ \\
15 & $1.00 \pm 0.19$ & $0.60 \pm 0.05$ & $1.44 \pm 0.03$ & $59.86 \pm 5.44$ & $0.415 \pm 0.004$ \\
\hline
\end{tabular}


The absorption efficiency (AE) was then quantified, according to Conover (1966), as

$$
\mathrm{AE}=(F-E) /(1-E) F
$$

where $F$ and $E$ are the organic contents (by weight) of food and faeces, respectively.

The absorption rate (AR) was calculated as the product of the organic ingestion rate (IR) and the absorption efficiency (AE).

Metabolic rate $\left(\mathrm{VO}_{2}\right)$ : The metabolic rate was obtained by measuring the oxygen consumption $\left(\mathrm{VO}_{2}\right)$. Mussels were individually placed in closed $780 \mathrm{ml}$ cylindrical chambers (height $85 \mathrm{~mm}$, diameter $115 \mathrm{~mm}$ ) sealed with oxygen probes (YSI ${ }^{\circledR} 5730$ ). The oxygen concentration was recorded at regular intervals with oxygen meters (YSI ${ }^{\oplus} 58$ ) connected to the probes for approximately $60 \mathrm{~min}$, until the oxygen concentration fell below $30 \%$ of the initial value. One parallel control chamber without animals was always used to correct for bacterial respiration, electrode drift, etc.

Ammonia excretion rate $\left(\mathrm{VNH}_{4^{-}} \mathrm{N}\right)$ : Rate of ammonia excretion was determined by placing mussels individually in closed chambers filled with $250 \mathrm{ml}$ airsaturated water previously filtered through $0.2 \mu \mathrm{m}$ Millipore membranes. After $150 \mathrm{~min}, 10 \mathrm{ml}$ samples of the water were extracted from each experimental chamber to be analysed following Solorzano's method (1969).

Scope for growth (SFG) and net growth efficiency $\left(K_{2}\right)$ : SFG is defined as that fraction of the absorbed energy available for the somatic and/or gametogenic growth once metabolic requirements have been met (Widdows 1985). Accordingly, SFG is computed following the equation for the energetic balance developed by Winberg (1960) and Ivlev (1966):

$$
\mathrm{SFG}=I-F a e-M=\mathrm{AR}-M
$$

where $I$ is the ingested energy, Fae is the energy loss in the faeces, $M$ summarizes the metabolic expenditure plus the energy loss due to excretion; AR is the absorbed energy, computed as the product of ingestion rate and absorption efficiency.

The following energy conversion factors were used, as taken from Bayne et al. (1985):

$1 \mathrm{mg}$ POM $=23.5$ Joules

$1 \mathrm{ml} \mathrm{O}_{2}=20.36$ Joules

$1 \mu \mathrm{g} \mathrm{NH} \mathrm{NH}_{4}-\mathrm{N}=0.0249$ Joules

Net growth efficiency $\left(K_{2}\right)$ was calculated by the formula:

$$
K_{2}=\mathrm{SFG} / \mathrm{AR}
$$

Size standardization. To preclude variability in physiological rates caused by size differences, these rates were corrected to a standard-sized individual. To this end, once physiological measurements were com- pleted, shell length of each individual was recorded to the nearest $0.1 \mathrm{~mm}$ with vernier callipers and the soft tissues excised from the shell, dried at $110^{\circ} \mathrm{C}$ for $12 \mathrm{~h}$ and weighed. Physiological rates were then standarized to a $1 \mathrm{~g}$ dry weight individual, following the formula (Bayne et al. 1987)

$$
Y_{\mathrm{s}}=\left(1 / W_{\mathrm{e}}\right)^{b} Y_{\mathrm{e}}
$$

where $Y_{\mathrm{S}}$ and $Y_{\mathrm{e}}$ are the corrected and non-corrected physiological rates, respectively, $W_{\mathrm{e}}$ is the dry weight (in g) of the individual mussel and $b$ is the power value that scales physiological rate to body weight.

Used $b$ values were 0.53 for the clearance rate of Mytilus galloprovincialis in Ria de Arousa (PérezCamacho \& González 1984), 0.75 for the oxygen consumption (Bayne \& Newell 1983), and 0.72 for the ammonia excretion (Hawkins et al. 1985). No size standardization of the absorption efficiency is required (Bayne \& Newell 1983).

Clearance rates are also standarized to a $60 \mathrm{~mm}$ shell length individual following the formula

$$
\mathrm{CR}_{\mathrm{s}}=\mathrm{CR}_{\mathrm{e}}\left(60 / L_{\mathrm{e}}\right)^{b}
$$

where $\mathrm{CR}_{\mathrm{s}}$ and $\mathrm{CR}_{\mathrm{e}}$ are the standardized and the nonstandardized clearance rates, respectively, $L_{\mathrm{e}}$ is the length (in $\mathrm{mm}$ ) of the experimental animal and $b=1.85$ (Pérez-Camacho \& González 1984).

Statistical analysis. Comparison of means for the different physiological parameters was carried out by means of standard analysis of variance (ANOVA). Homogeneity of variance was checked by Bartlett's test and correction for heterogeneity (when required) was performed by reciprocal or logarithmic transformation of data.

A. 2-factor ANOVA (Zar 1984) was used to test the effects of both the time of maintenance in the labora tory and origin of mussels.

\section{RESULTS}

\section{Physiological parameters}

Results of physiological parameters after 1 and $15 \mathrm{~d}$ maintenance under the experimental diet are presented in Table 3. All physiological rates were standardized to $1 \mathrm{~g}$ dry weight of soft tissues; clearance rates were also standardized to $60 \mathrm{~mm}$ shell length.

\section{Clearance rates $(\mathrm{CR})$}

Results of a 2-factor ANOVA developed to test the statistical significance of differences in physiological parameters are shown in Table 4 
Table 3. Mytilus galloprovincialis. Values of physiological parameters (mean $\pm \mathrm{SD}, \mathrm{n}=16$ ) standarized to $1 \mathrm{~g} \mathrm{dry}$ weight or $60 \mathrm{~mm}$ shell length mussels kept in the laboratory on an experimental diet. CR: Clearance rate; IR: ingestion rate, AE: absorption efficiency; $\mathrm{VO}_{2}$ : oxygen uptake rate; $\mathrm{VNH}_{4}-\mathrm{N}$ : ammonia excretion rate

\begin{tabular}{|c|c|c|c|c|c|c|c|c|}
\hline Orignn & Day & $\begin{array}{l}\text { Weight-specific } \\
\text { CR }\left(\mathrm{I} \mathrm{h}^{-1}\right)\end{array}$ & $\begin{array}{l}\text { Length-specific } \\
\left.\qquad C R(] h^{-1}\right)\end{array}$ & $\begin{array}{l}\text { Weight-specific } \\
\text { IR }\left(\mathrm{mg} \text { org } \mathrm{h}^{-1}\right)\end{array}$ & $\begin{array}{l}\text { Length-specific } \\
\left.\text { IR (mg org } \mathrm{h}^{-1}\right)\end{array}$ & $\mathrm{AE}$ & $\begin{array}{c}\mathrm{VO}_{2} \\
\left\{\mathrm{ml} \mathrm{O} \mathrm{h}^{-1}\right\}\end{array}$ & $\begin{array}{c}\mathrm{VNH}_{4}-\mathrm{N} \\
\left(\mu g \mathrm{NH}_{4}-\mathrm{Nh}^{-1}\right)\end{array}$ \\
\hline Intertidal & 1 & $3.51 \pm 1.20$ & $4.46 \pm 1.63$ & $1.97 \pm 0.67$ & $2.50 \pm 0.91$ & $0.39 \pm 0.07$ & $0.46 \pm 0.14$ & $6.10 \pm 4.09$ \\
\hline Intertidal & 15 & $4.33 \pm 0.98$ & $5.66 \pm 1.48$ & $2.56 \pm 0.58$ & $3.34 \pm 0.87$ & $0.33 \pm 0.09$ & $0.35 \pm 0.03$ & $4.92 \pm 1.04$ \\
\hline Raft & 1 & $5.26 \pm 1.81$ & $4.54 \pm 1.60$ & $2.95 \pm 1.01$ & $2.54 \pm 0.91$ & $0.52 \pm 0.08$ & $0.40 \pm 0.07$ & $8.02 \pm 1.64$ \\
\hline Raft & 15 & $6.46 \pm 1.08$ & $5.35 \pm 0.90$ & $3.81 \pm 0.64$ & $3.15 \pm 0.53$ & $0.47 \pm 0.07$ & $0.36 \pm 0.11$ & $8.17 \pm 1.93$ \\
\hline
\end{tabular}

Table 4. Results of 2-factor ANOVA performed to test the effects of both time maintenance in the laboratory and the origin of mussels. ns: not significant, $p<0.05, \cdots p<0.01$,

$$
\cdots p<0.001
$$

\begin{tabular}{|c|c|c|c|c|}
\hline Source & $\begin{array}{l}\text { Sum of } \\
\text { square }\end{array}$ & $\mathrm{df}$ & $\begin{array}{l}\text { Mean } \\
\text { square }\end{array}$ & F-ratio \\
\hline \multicolumn{5}{|c|}{ Weight-specific clearance rate } \\
\hline Time & 13.281 & 1 & 13.281 & $7.679 \cdots$ \\
\hline Origin & 49.240 & 1 & 49.240 & $28.468 \cdots$ \\
\hline Time $\times$ Origin & 0.464 & 1 & 0.464 & $0.268 \mathrm{~ns}$ \\
\hline Error & 84.753 & 49 & 1.730 & \\
\hline \multicolumn{5}{|c|}{ Length-specific clearance rate } \\
\hline Time & 13.238 & 1 & 13.238 & $6.542 \cdots$ \\
\hline Origin & 0.182 & 1 & 0.182 & $0.090 \mathrm{~ns}$ \\
\hline Time $\times$ Origin & 0.495 & 1 & 0.495 & $0.244 \mathrm{~ns}$ \\
\hline Error & 99.156 & 49 & 2.024 & \\
\hline \multicolumn{5}{|c|}{ Absorption efficiency } \\
\hline Time & 223.094 & 1 & 223.094 & $3.801 \mathrm{~ns}$ \\
\hline Origin & 1132.656 & 1 & 1132.656 & $19.297 \cdots$ \\
\hline Time $\times$ Origin & 0.777 & 1 & 0.777 & $0.013 \mathrm{~ns}$ \\
\hline Error & 1408.719 & 24 & 58.697 & \\
\hline \multicolumn{5}{|c|}{ Oxygen uptake rate } \\
\hline Time & 0.189 & 1 & 0.189 & $8.988^{\cdots}$ \\
\hline Origin & 0.054 & 1 & 0.054 & $2.581 \mathrm{~ns}$ \\
\hline Time $\times$ Origin & 0.103 & 1 & 0.103 & $4.891^{\circ}$ \\
\hline Error & 2.059 & 98 & 0.021 & \\
\hline \multicolumn{5}{|c|}{ Ammonia excretion } \\
\hline Time & 1.355 & 1 & 1.355 & $0.250 \mathrm{~ns}$ \\
\hline Origin & 34.526 & 1 & 34.526 & $6.369^{\circ}$ \\
\hline Time $\times$ Origin & 2.309 & 1 & 2.309 & $0.426 \mathrm{~ns}$ \\
\hline Error & 97.571 & 18 & 5.421 & \\
\hline
\end{tabular}

For weight-specific CR, this analysis indicated that both sources of variation exerted significant effects, differences among origins having higher significance $(p<0.001)$ than those associated with time $(p<0.05)$. Thus habitat is the main factor of variation for CR, explaining $33.33 \%$ of the total variation, whereas the time of experimentation would only explain $8.99 \%$ of the total variation.

Nevertheless, differences associated with the origin of mussels disappeared when CR was standardized to shell length. After this standardization, only time exerted significant differences $(p<0.01)$, this factor explaining $11.71 \%$ of total variation.

\section{Absorption efficiency (AE)}

The analysis of variancc performed on AE values showed significant differences only among origins, these being highly significant $(p<0.001)$. This factor explains $40.95 \%$ of total variation in $\mathrm{AE}$. The $\mathrm{AE}$ of cultured mussels was between 1.3 and $1.4(p<0.05)$ times the AE of intertidal mussels (Table 3). AE decreased during the maintenance period in mussels from both origins.

\section{Rates of oxygen consumption $\left(\mathrm{VO}_{2}\right)$}

Time of maintenance in the laboratory was the only significant source of variation $(p<0.01)$ regarding rates of oxygen consumption (Table 4). This factor explains only $7.86 \%$ of the total variation. Significance of the interaction term (Table 4) indicates that maximum differences in $\mathrm{VO}_{2}$ between origins occurred at the start of experiments (Day 1) but these differences tended to disappear by Day 15 (Table 3).

\section{Rates of ammonia excretion $\left(\mathrm{VNH}_{4}-\mathrm{N}\right)$}

The ANOVA for $\mathrm{VNH}_{4}-\mathrm{N}$ showed significant differences only between origins ( $p<0.05)$, which caused $25.43 \%$ of the total variation. Raft mussels presented higher values of ammonia excretion rate than did the intertidal mussels (Table 3 ).

\section{SFG and net growth efficiency $\left(K_{2}\right)$}

Values for the components of the energy budget and resultant SFG and $K_{2}$ are given in Table 5. Due to the great differences in body condition between mussels of different origin (intertidal and raft cultivated), results 
Table 5. Components of the energy budget (means of 16 replicates) calculated for a standard mussel of $1 \mathrm{~g} d r y$ weight and $60 \mathrm{~mm}$ shell length. AR: absorption rate; SFG: scope for growth; $K_{2}$ : net growth efficiency. See 'Material and methods' for details of calculations and Table 3 for other abbreviations

\begin{tabular}{|c|c|c|c|c|c|c|c|c|c|}
\hline Origin & Day & Standardization & $\begin{array}{c}I R \\
\left(\mathrm{~J} \mathrm{~h}^{-1}\right)\end{array}$ & $\mathrm{AE}$ & $\begin{array}{c}\mathrm{AR} \\
\left(\mathrm{J} \mathrm{h}^{-1}\right)\end{array}$ & $\begin{array}{c}\mathrm{VO}_{2} \\
\left(\mathrm{~J} \mathrm{~h}^{-1}\right)\end{array}$ & $\begin{array}{c}\mathrm{VNH}_{4}-\mathrm{N} \\
\left(\mathrm{J} \mathrm{h}^{-1}\right)\end{array}$ & $\begin{array}{l}\mathrm{SFG} \\
\left(\mathrm{J} \mathrm{h}^{-1}\right)\end{array}$ & $K_{2}(\times 100)$ \\
\hline Intertidal & 1 & $\begin{array}{l}\text { Shell length } \\
\text { Weight }\end{array}$ & $\begin{array}{l}58.73 \\
46.25\end{array}$ & 39.0 & $\begin{array}{l}22.90 \\
18.04\end{array}$ & 9.37 & 0.15 & $\begin{array}{r}13.39 \\
8.52\end{array}$ & $\begin{array}{l}58.44 \\
47.23\end{array}$ \\
\hline Intertidal & 15 & $\begin{array}{l}\text { Shell length } \\
\text { Weight }\end{array}$ & $\begin{array}{l}78.47 \\
60.07\end{array}$ & 33.0 & $\begin{array}{l}25.89 \\
19.82\end{array}$ & 7.11 & 0.12 & $\begin{array}{l}18.67 \\
12.59\end{array}$ & $\begin{array}{l}72.09 \\
63.09\end{array}$ \\
\hline Raft & 1 & $\begin{array}{l}\text { Shell length } \\
\text { Weight }\end{array}$ & $\begin{array}{l}59.71 \\
69.33\end{array}$ & 52.0 & $\begin{array}{l}31.05 \\
36.05\end{array}$ & 8.14 & 0.20 & $\begin{array}{l}22.71 \\
27.71\end{array}$ & $\begin{array}{l}73.13 \\
76.86\end{array}$ \\
\hline Raft & 15 & $\begin{array}{l}\text { Shell length } \\
\text { Weight }\end{array}$ & $\begin{array}{l}74.14 \\
89.54\end{array}$ & 47.0 & $\begin{array}{l}34.85 \\
42.08\end{array}$ & 7.37 & 0.20 & $\begin{array}{l}27.27 \\
34.51\end{array}$ & $\begin{array}{l}78.27 \\
82.00\end{array}$ \\
\hline
\end{tabular}

are greatly influenced by the parameter chosen for size standardization. For weight standardization, SFG values were 3.3 times greater in raft mussels than in intertidal mussels. After $15 \mathrm{~d}$ under laboratory experimental conditions, mussels of both origins had increased SFG, and differences between origins had decreased.

The same trends were observed for SFG values standardized to shell length, although the magnitude of differences was less: SFG was $69.6 \%$ higher in cultivated compared with intertidal mussels at the start of experiments, this difference having decreased to $46.1 \%$ by Day 15 as a consequence of the differential increment experienced by both groups with time in the laboratory $(39.4 \%$ in intertidal compared with $20.2 \%$ in raft mussels). $K_{2}$ essentially reflected the patterns of SFG (Table 5).

\section{DISCUSSION}

The present work was primarily designed to analyze physiological differences between mussels from 2 origins in the Ría de Arousa. In this respect, results showed significant differences in several physiological parameters; namely, clearance rate, absorption efficiency and rate of ammonia excretion, while no differences in metabolism were found. The observed tendencies were higher weight-specific $C R$, higher $A E$ and higher $\mathrm{VNH}_{4}-\mathrm{N}$ in cultivated mussels, which can be expressed in quantitative terms as follows: origin of mussels explained $33.3 \%$ of variation in weight-specific CR, $41.0 \%$ of $\mathrm{AE}$ and $25.4 \%$ of ammonia excretion. Time of maintenance in the laboratory explained Comparatively less variation: 8 to $9 \%$ in the case of $C R$, $\mathrm{AE}$ and $\mathrm{VO}_{2}$ and only $1 \%$ in $\mathrm{VNH}_{4}-\mathrm{N}$.

ANOVA (Table 4) also showed that significance of differences in CR between origins disappears when this parameter is standardized to shell length instead of soft body weight, and this feature deserves a specific discussion. Mussels were chosen with a similar shell size in both groups $(\sim 60 \mathrm{~mm})$, but mean soft body weight of specimens collected from the intertidal habitat was about twice the weight of those cultivated on rafts (Table 1). Very likely, this difference in body condition reflects different phases of the breeding cycle in the 2 groups of mussels, with cultivated specimens occurring in the postspawning stage. Whatever the cause, this difference explains that results of the comparison are variable depending on the standardization parameter. Iglesias et al. (1996) found similar results when comparing physiological behaviour of mussels cultivated in different sites within the Ría de Arousa. As discussed by these authors, regarding clearance rate, shell size is a more convenient reference parameter than body weight for comparative purposes, given that CR is primarily determined by the branchial area, which is closely related to shell length (Hughes 1969).

Effects associated with the origin have been considered by many authors to be an indication of the existence of genetic differences between mussels from separate sites. This factor would produce differences in growth rate (Rawson \& Hilbish 1991), in filtration and net growth rates (Widdows et al. 1984), as well as in mortality (Dickie et al. 1984). Alternatively, Mallet et al. (1987) suggested these effects would reflect the differential influences undergone by mussels during their pre-experimental stage, so conforming to an 'ecological memory' of the individuals with respect to the conditions experienced in the primary habitat (food availability and quality, tidal air exposure, etc.).

Okumus \& Stirling (1994) established a positive correlation between clearance rate and POM values in 2 populations of Mytilus edulis. Thus, under the homogeneous food conditions provided in the present experiments, recorded differences in CR could be attributed to this 'ecological memory'. In fact, CR variability of mussels from 2 locations in Ría de Arousa subjected to diets of different quality was only partly 
accounted for by nutritional experimental conditions while conditions prevailing at these sites also appear to explain a part of the variability (Navarro et al. 1996). As regards these environmental conditions, the main difference between the 2 groups of mussels studied in the present work is likely to be caused by the food shortage experienced by intertidal specimens during air exposure, a factor that has been identified as strongly limiting to mussel growth (Peterson \& Black 1988).

Ingestion rate tended to increase significantly ( $p<$ 0.05) with time of maintenance in the laboratory in both groups of mussels (Fig 1). Under these conditions, net absorption efficiency would tend to decrease in bivalves, due to both the morphological limits imposed by faster passage of food through the gut and the increased costs of digestion represented by endogenous losses (Navarro et al. 1994). However, no significant decrease of AE was recorded (Table 4), suggesting that digestive adaptation in terms of increased capacity had taken place after $15 \mathrm{~d}$ exposure to
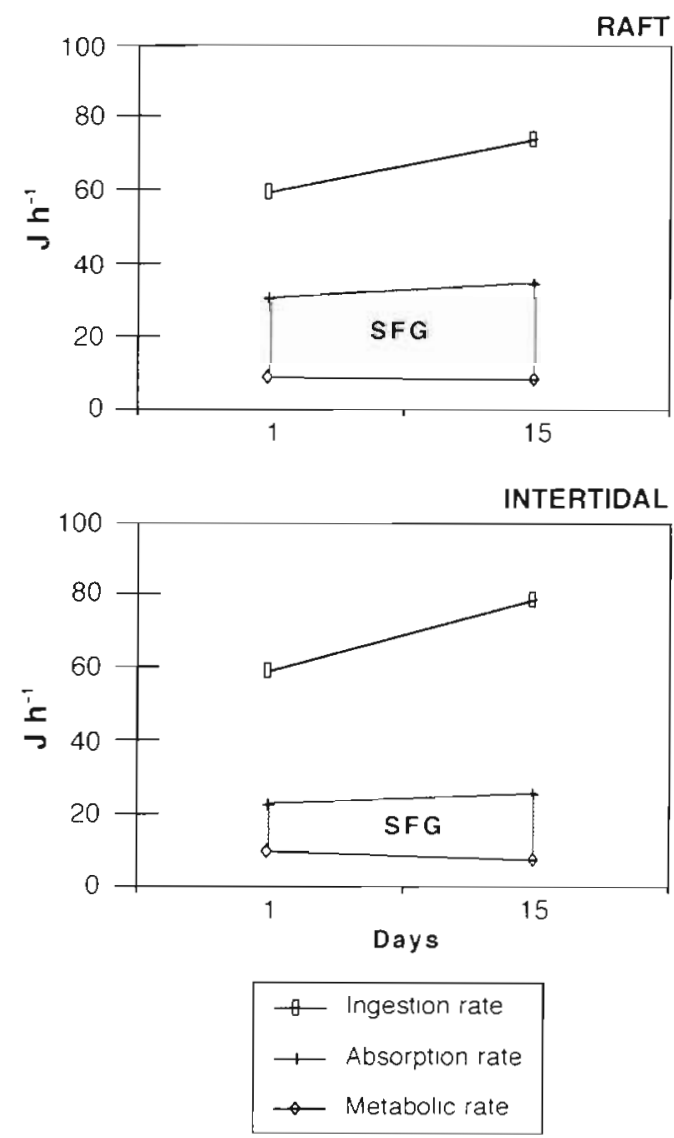

Fig. 1 Mytilus galloprovincialis. Components of the energy budget for mussels kept in the laboratory on an experimental diet. Physiological rates were standardized to shell length. Metabolic rate represents both oxygen consumption and excretion losses. SFG: scope for growth improved nutritional conditions in the laboratory. This response could be similar to the one reported in Cerastoderma edule involving increases in both the digestive spaces and digestive enzyme activities (Larretxea 1995, Ibarrola 1996).

The importance of the above processes can be further discussed in the context of SFG values according to the evidence described by Navarro et al. (1991) relating to the fine correspondence between SFG and actual growth. However, Jørgensen (1996) has recently criticised this paper, not based on his usual arguments against SFG values (poor food values due to laboratory conditions), but rather on the fact that mussels can undergo alterations in their physiological responses due to previous removal from raft ropes. In the present study, after $15 \mathrm{~d}$ exposure to experimental diets, intertidal mussels increased their SFG by $39.4 \%$, while the increment was $20.2 \%$ for cultivated mussels. This response is partly accounted for by the increase in absorption rate, although the main effect corresponds to the significant decline in metabolism over the maintenance time (Tables $4 \& 5$ ). On the other hand, the general improvement of growth conditions from Day 1 to Day 15 contrasts with the slight weight loss recorded in that period (see Table 1). This anomaly could be explained by high variances associated with mean dry weight determinations for the different conditions. In fact, differences between means for Days 1 and 15 are non-significant within each group, and weight increments computed for a $15 \mathrm{~d}$ period from SFG values in Table 5 (mean 18\%) are below the coefficient of variation of body weight estimates ( 20 to $30 \%$ ).

In spite of the fact that intertidal mussels appear to respond better to the improvement of feeding conditions occurring during maintenance in the laboratory and tend to catch up with cultivated specimens in terms of growth rate, initial differences in SFG were reduced by less than $10 \%$ after $15 \mathrm{~d}$. This difference essentially corresponds to higher values of AE systematically recorded for cultivated mussels. This indicates that $\mathrm{AE}$ is the physiological parameter showing a more persistent behaviour with respect to habitat and one on which the 'ecological memory' has more influence.

Acknowledgements. We thank Dr Enrique Navarro for valuable comments and suggestions that greatly improved an earlier version of this manuscript. We also thank Lourdes Nieto and Beatriz Gonzalez for technical assistance. This work was supported by Project XUGA 40201 B 94 of the Conselleria de Educación, Xunta de Galicia

\section{LITERATURE CITED}

Bayne BL, Brown DA, Burns $K$, Dixon DR, Ivanovici A, Livingstone DR, Lowe DM, Moore MN, Stebbing ARD, Widdows J (1985) The effects of stress and pollution on marine animals. Praeger, New York 
Bayne BL, Hawkins AJS, Navarro E (1987) Feeding and digestion by the mussel Mytilus edulis L. (Bivalvia: Mollusca) in mixtures of silt and algal cells at low concentrations. J Exp Mar Biol Ecol 111:1-22

Bayne BL, Hawkins SJS, Navarro E, Iglesias JIP (1989) Effects of seston concentration on feeding, digestion and growth in the mussel Mytilus edulis. Mar Ecol Prog Ser 55: $47-54$

Bayne BL, Klumpp DW, Clarke KR (1984) Aspects of feeding, including estimates of gut residence time, in three mytilid species (Bivalvia, Mollusca) at two contrasting sites in the Cape Peninsula, South Africa. Oecologia 64:26-33

Bayne BL, Newell RC (1983) Physiological energetics of marine molluscs. In: Saleudin ASM, Wilburg KM (eds) The Mollusca Vol 4(1). Academic Press, New York, p 407-499

Conover RJ (1966) Assimilation of organic matter by zooplankton. Limnol Oceanogr 11:338-354

Coughland J (1969) The estimation of filtering rate from the clearance of suspensions. Mar Biol 2:356-358

Dickie LM, Boudreaup PR, Freeman FR (1984) Influences of stock and site on growth and mortality in the blue mussel (Mytilus edulis). Can J Fish Aquat Sci 41:225-236

Hawkins AJS, Salkeld PN, Bayne BL, Gnaiger E, Lowe DM, (1985) Feeding and resource allocation in the mussel Mytilus edulis: evidence for time-averaged optimization. Mar Ecol Prog Ser 20:273-287

Hildreth DI, Crisp DJ (1976) A corrected formula for calculation of filtration rate of bivalve molluscs in an experimental flowing system. J Mar Biol Assoc UK 56:111-120

Hughes RN (1969) A study of feeding in Scrobicularia plana. J Mar Biol Assoc UK 49:805-823

Ibarrola I (1996) Adaptaciones digestivas en el berberecho Cerastoderma edule sometido a variaciones en la cantidad y el contenido orgánico de la dieta: implicaciones energéticas. PhD thesis, Universidad del País Vasco, Bilbao

Iglesias JIP, Pérez-Camacho A, Navarro E, Labarta U, Beiras R, Hawkins AJS, Widdows J (1996) Microgeographic variability in feeding, absorption and condition of mussels (Mytilus galloprovincialis Lmk): a transplant experiment. J Shellfish Res 15(3):673-680

Ivlev VS (1966) The biological productivity of waters. J Fish Res Board Can 23(11):1727-1759

Jorgensen CB (1996) Bivalve filter feeding revisited. Mar Ecol Prog Ser 142:287-302

Larretxea X (1995) Estudios de crecimiento en Cerastoderma edule $\mathrm{L}$. base fisiológicas de la producción individual. $\mathrm{PhD}$ thesis. Universidad del País Vasco, Bilbao

Mallet AL, Carver CEA, Coffen SS, Freeman KR (1987) Winter growth of the blue mussel Mytilus edulis L.: impor-

This article was submitted to the editor tance of stock and site. J Exp Mar Biol Ecol 108:217-228

Navarro E, Iglesias JIP, Ortega MM, Larretxea X (1994) The basis for a functional response to variable food quantity and quality in cockles Cerastoderma edule (Bivalvia, Cardidae). Physiol Zool 67(2):468-496

Navarro E, Iglesias JIP, Perez-Camacho A, Labarta U (1996) The effect of diets of phytoplancton and suspended bottom materials on feeding and absorption of raft mussels (Mytilus galloprovincialis Lmk.) J Exp Mar Biol Ecol 198: $175-189$

Navarro E, Iglesias JIP, Perez-Camacho A, Labarta U, Beiras $\mathrm{R}$ (1991) The physiological energetics of mussels (Mytilus galloprovincialis $\mathrm{Lmk}$ ) from different cultivation rafts in the Ria de Arosa (Galicia, NW Spain). Aquaculture 94: $197-212$

Okumus I, Stirling HP (1994) Physiological energetics of cultivated mussel (Mytllus edulis) populations in 2 scottish west coast sea lochs. Mar Biol 119:125-131

Perez-Camacho A, Gonzalez R (1984) La filtración del mejillón (Mytilus edulis L.) en laboratorio. Actas do Primeiro Seminario de Ciencias do Mar, As R'as Galegas, Cuadernos da Area de Ciencias Marinas, Seminario de Estudos Galegos 1:427-437

Peterson $\mathrm{CH}$, Black R (1988) Responses of growth to elevation fail to explain vertical zonation of suspension-feeding bivalves on a tidal flat. Oecologia 76:423-429

Rawson PD, Hilbish TJ (1991) Genotype-environment interaction for juvenile growth in the hard clam Mercenaria mercenaria (L.). Evolution 45:1924-1935

Solorzano L (1969) Determination of ammonia in natural seawaters by the phenol-hypochlorite method. Limnol Oceanogr 14:799-801

Widdows J (1985) Physiological procedures. In: Bayne BL, Brown DA, Burns $\mathrm{K}$, Dixon DR, Ivanovici A, Livingstone DR, Lowe DM, Moore MN, Stebbing ARD, Widdows J (eds) The effects of stress and pollution on marine animals. Praeger, New York, p 161-178

Widdows J, Donkin P, Salkeld PN, Cleary JJ, Lowe DM, Evans SV, Thompson PE (1984) Relative importance of environmental factors in determining physiological differences between two populations of mussels (Mytilus edulis). Mar Ecol Prog Ser 17:33-48

Widdows J, Johnson D (1988) Physiological energetics of Mytilus edulis: scope for growth. Mar Ecol Prog Ser 46 : $113-121$

Winberg GG (1960) Rate of metabolism and food requirements of fishes. Fish Res Board Can Transl Ser 194

Zar JH (1984) Biostatistical analysis. Prentice-Hall, Englewood Cliffs, NJ

Manuscript first received: September 16, 1996

Revised version accepted: April 7, 1997 